\title{
Biological characterisation of the emerged highly pathogenic avian influenza (HPAI) A(H7N9) viruses in humans, in mainland China, 2016 to 2017
}

W Zhu ${ }^{12}$, J Zhou ${ }^{12}$, Z Li ${ }^{12}$, L Yang ${ }^{1}$, X Li ${ }^{1}$, W Huang ${ }^{1}$, S Zou ${ }^{1}$, W Chen ${ }^{1}$, H Wei ${ }^{1}$, J Tang ${ }^{1}$, L Liu ${ }^{1}$, J Dong ${ }^{1}$, D Wang ${ }^{1}$, Y Shu ${ }^{1}$

1. National Institute for Viral Disease Control and Prevention, China Centers for Disease Control and Prevention, Key Laboratory for Medical Virology, National Health and Family Planning Commission, Beijing, China

2. These authors contributed equally to this work

Correspondence: Yuelong Shu (yshu@cnic.org.cn)

Zhu W, Zhou J, Li Z, Yang L, Li X, Huang W, Zou S, Chen W, Wei H, Tang J, Liu L, Dong J, Wang D, Shu Y. Biological characterisation of the emerged highly pathogenic avian influenza (HPAl) A(H7N9) viruses in humans, in mainland China, 2016 to 2017. Euro Surveill. 2017;22(19):pii=30533. DOI: http://dx.doi.org/10.2807/15607917.ES.2017.22.19.30533

Article submitted on 14 April 2017 / accepted on 10 May 2017 / published on 11 May 2017

With no or low virulence in poultry, avian influenza $A\left(\mathrm{H}_{7} \mathrm{~N} 9\right)$ virus has caused severe infections in humans. In the current fifth epidemic wave, a highly pathogenic avian influenza (HPAI) $\mathrm{H}_{7} \mathrm{~N} 9$ virus emerged. The insertion of four amino acids (KRTA) at the haemagglutinin (HA) cleavage site enabled trypsin-independent infectivity of this virus. Although maintaining dual receptor-binding preference, its HA antigenicity was distinct from low-pathogenic avian influenza $\mathrm{A}\left(\mathrm{H}_{7} \mathrm{~N} 9\right)$. The neuraminidase substitution $\mathrm{R} 292 \mathrm{~K}$ conferred a multidrug resistance phenotype.

Five outbreak waves have occurred since the lowpathogenic avian influenza $\mathrm{A}\left(\mathrm{H}_{7} \mathrm{~N} 9\right)$ virus (LPAI $\mathrm{H}_{7} \mathrm{~N}$ ) first emerged in spring 2013 in eastern China [1]. Highly pathogenic avian influenza $A\left(\mathrm{H}_{7} \mathrm{~N} 9\right)$ (HPAl $\mathrm{H}_{7} \mathrm{~N} 9$ ) viruses, derived from their LPAI $\mathrm{H}_{7} \mathrm{~N} 9$ counterparts, have recently been isolated from humans and resulted in fatal outcome in Guangdong, China (A/Guangdong/17SFo03/2016 (SFo03) and $\mathrm{A} /$ Guangdong/17SFo06/2017 (SFoo6)) [2]. Both viruses contain an insertion of four amino acids (KRTA) in the haemagglutinin ( $\mathrm{HA})$ proteolytic cleavage site, indicating their pathotype switch from LPAI to HPAI. Furthermore, they retain a series of genetic features contributing to the ability to infect humans (e.g. 186V in the $\mathrm{HA}$ protein ( $\mathrm{H}_{3}$ numbering) and $627 \mathrm{~K}$ in the $\mathrm{PB} 2$ protein) that raise concerns regarding their pandemic potential. Amino acid substitutions associated with resistance to neuraminidase inhibitors (NAIs) have been detected in both $\mathrm{SFoo3}_{3}$ and SFoo6 viruses. Therefore, to update public health risk assessment, we investigated trypsin-dependent infectivity, receptor binding properties, antigenic alternations of the HPAI $\mathrm{H}_{7} \mathrm{~N} 9$ viruses, as well as their sensitivity to antiviral drugs. All LPAI H7N9 viruses in this study were isolated from humans.

\section{Similar replication ability of HPAI H7N9 viruses with or without trypsin}

Avian influenza viruses with multiple basic amino acids at the HA cleavage site are able to replicate in cell culture in the absence of $\mathrm{N}$-p-tosyl-L-phenylalanine chloromethyl ketone-treated (TPCK) trypsin [3]. We therefore examined the in vitro growth of $\mathrm{SFoo3}$ and SFoo6 in MDCK cells in the presence or absence of TPCK trypsin. Cells were fixed with ice-cold $4 \%$ paraformaldehyde complemented with Triton X-100 and detected by staining of the nucleoprotein (NP). LPAI $\mathrm{H}_{7} \mathrm{~N} 9$ virus (A/Anhui/1/2013 $\left(\mathrm{AnH}_{1}\right)$ ) and $\mathrm{HPAl} \mathrm{H}_{5} \mathrm{~N} 6$ virus (A/ Guangdong/99710/2014 (GD710)) were included as control. The three HPAI viruses (GD710, SFoo3 and SFoo6) had comparable ability to replicate both in the presence and absence of TPCK trypsin, while the LPAI $\mathrm{H}_{7} \mathrm{~N}_{9} \mathrm{AnH}_{1}$ virus failed to replicate in the absence of TPCK trypsin (Figure 1).

\section{Dual receptor-binding profile of HPAI H7N9 viruses}

HA amino acids $226 \mathrm{~L} / \mathrm{I}$ and $186 \mathrm{~V}$ have been reported to contribute to the dual receptor binding properties of the LPAI H7N9 viruses [4,5]. However, 226L has mutated back to $226 \mathrm{Q}$ in the HPAI $\mathrm{H} 7 \mathrm{~N} 9$ viruses. In order to verify whether the receptor-binding profile of HPAI $\mathrm{H}_{7} \mathrm{~N} 9$ differed from the LPAI viruses, we conducted a binding assay with synthetic sialylglycopolymers. The sialylglycopolymers, including 3'-SLN, 3'-SLN-LN, 6'-SLN and 6'SLN-LN (LN corresponds to lactosamine (Galß1-4GICNAC) and 3'SLN and 6'SLN, respectively, correspond to Neu5Ac a 2,3 and Neu5Ac a 2,6 linked to LN), were obtained from the Consortium of Functional Glycomics (http://www.functionalglycomics.org). As described previously [6,7], 32 haemagglutinating units (HAU) of live virus per well were used in the ELISA test. Binding was detected by a human chimeric anti- $\mathrm{H}_{7}$ monoclonal antibody (MoAb) or mouse-derived anti-N9 
Replication of highly pathogenic avian influenza A(H7N9) viruses from humans in MDCK cells with or without TPCK trypsin, China, 2016-2017 ( $=2)$

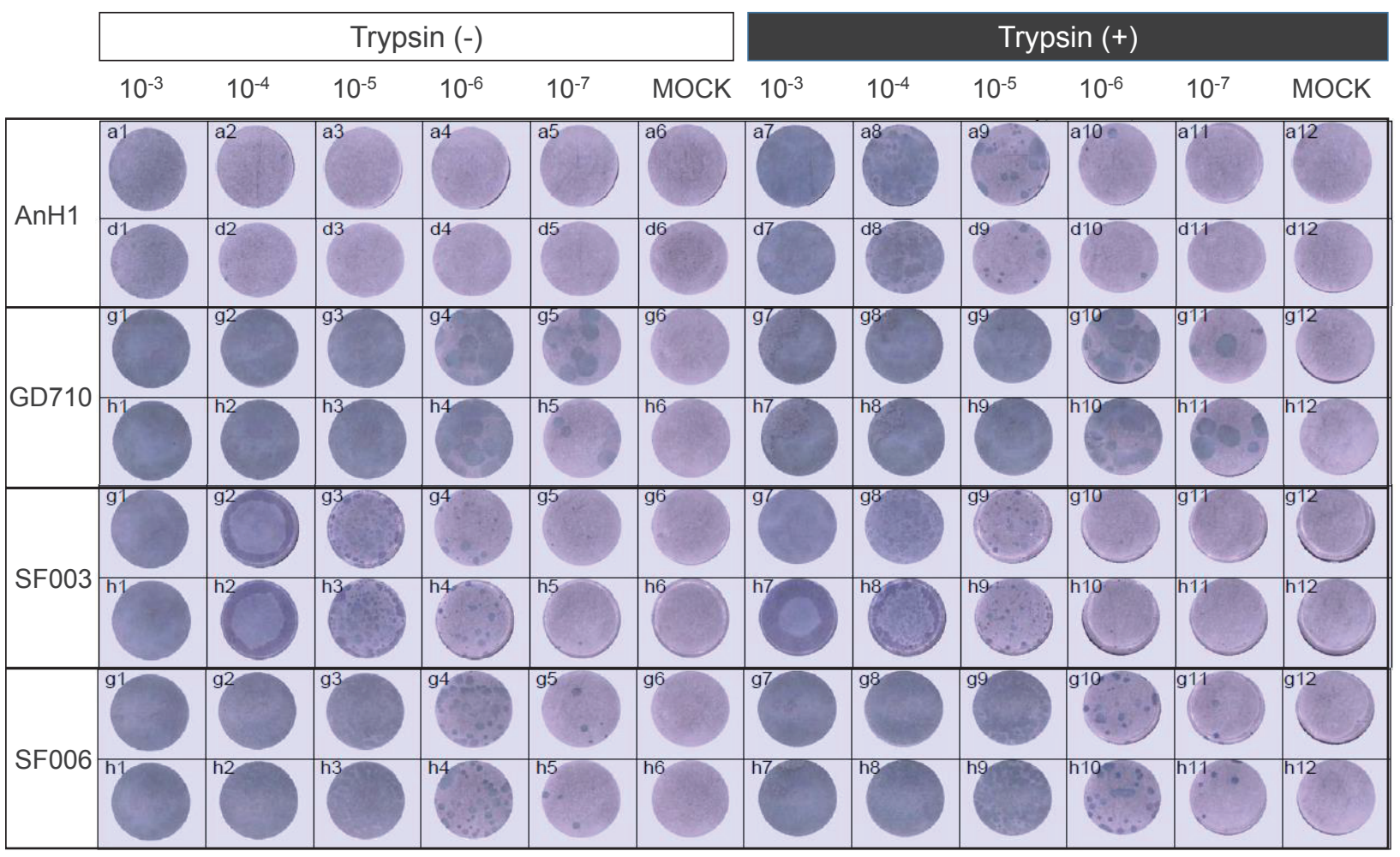

AnH1: A/Anhui/1/2013 (LPAI H7N9); GD710: A/Guangdong/99710/2014 (HPAI H5N6); MDCK: Madin-Darby canine kidney epithelium; PBS: phosphate-buffered saline; SFoo3: A/Guangdong/17SFo03/2016 (HPAl H7N9); SFoo6: A/Guangdong/17SFoo6/2017 (HPAI H7N9); TPCK: N-ptosyl-L-phenylalanine chloromethyl ketone-treated.

Serial viral dilutions of $10^{-3}, 10^{-4}, 10^{-5}, 10^{-6}$ and $10^{-7} \mathrm{TCID}_{50}$ were inoculated on MDCK cells. Mock cells were inoculated with PBS.

MoAb. The optical density was read at $450 / 630 \mathrm{~nm}$. As shown in Figure 2, the LPAI H7N9 AnH1 virus bound to sialic acid a2,3 and a2,6 receptors, as expected. The HPAI H7N9 viruses SFoo3 and SFoo6 showed typical dual receptor preference, with increased affinity to $a_{2,3}$ receptors compared with the LPAI $\mathrm{H}_{7} \mathrm{~N}_{9} \mathrm{AnH}_{1}$ virus. When using the anti-N9 monoclonal antibody, SFoo6 virus showed a slightly enhanced binding preference for $a_{2}, 6$ receptors compared with the $\mathrm{AnH}_{1}$ virus (Figure $2 \mathrm{C}$ ). This phenotype may be due to the binding of $\mathrm{N} 9$ to the human-type receptor as reported recently [8].

\section{Divergent antigenic properties of HPAI relative to LPAI H7N9 viruses}

Compared with the sequences of LPAI $\mathrm{H}_{7} \mathrm{~N} 9$ viruses, several substitutions, including I38T, S112P, K164E and $1317 \mathrm{~V}$ ( $\mathrm{H}_{7}$ numbering) have occurred in the $\mathrm{HA}_{1}$ protein of $\mathrm{HPAl} \mathrm{H}_{7} \mathrm{~N} 9$ viruses. To investigate the antigenic difference among HPAl and LPAI H7N9 viruses, a haemagglutination inhibition $(\mathrm{HI})$ assay was conducted using the ferret anti-sera against $A / A n h u i / 1 / 2013$ (wildtype), A/Anhui/1/2013 (reverse genetics) and $A /$ Shanghai/2/2013 (wildtype) according to standard protocols [9] (Table 1). Antigenic analysis demonstrated that all LPAI H7N9 viruses except A/Hunan/06948/2017 and $A / A n h u i / 60933 / 2016$ reacted well with ferret antiserum of $\mathrm{H}_{7} \mathrm{~N}_{9}$ vaccine strains $\mathrm{AnH}_{1}$ (either wild-type or reverse genetics strains) or $\mathrm{A} / \mathrm{Sh}$ anghai/2/2013 (Table 1). However, both HPAI H7N9 viruses (SFoo3 and SFoo6) showed low or no reactivity to antisera of LPAI $\mathrm{H}_{7} \mathrm{~N} 9$ vaccine strains.

\section{Multiple drug resistance of HPAI H7N9 viruses containing the $\mathrm{R} 292 \mathrm{~K}$ substitution}

The substitution R292K (N2 numbering), which is associated with reduced susceptibility to NAIs [4], has been reported in the $\mathrm{HPAI} \mathrm{H}_{7} \mathrm{~N} 9$ viruses. Considering the possible effect that quasispecies containing NA-292R/K may have on drug susceptibility, we first purified SFoo3 virus from plaques. Two virus clones with either amino acid $292 \mathrm{~K}$ or $292 \mathrm{R}$ in the NA protein, were analysed in a neuraminidase inhibition assay [10]. The susceptibility of the viruses was categorised by the criteria recommended by the World Health Organization (WHO) Antiviral Working Group [11]. As expected, the influenza $A\left(\mathrm{H}_{3} \mathrm{~N}_{2}\right)$ wild-type virus (A/BeijingHaidian/1942/2014) and the LPAI H7N9 wild-type virus 
Direct glycan receptor binding of highly pathogenic avian influenza A(H7N9) viruses from humans, China, 2016-2017 $(\mathrm{n}=2)$

A. SLN/anti-H7

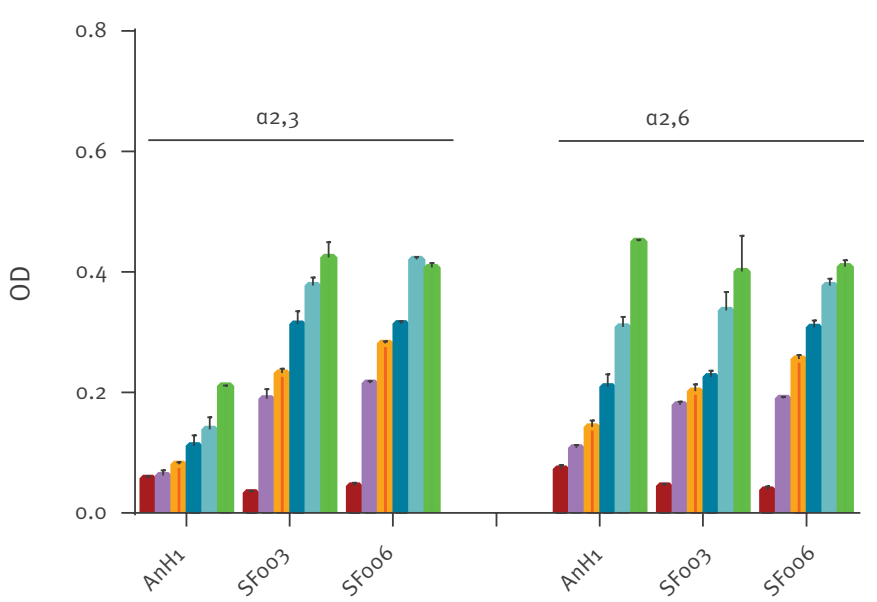

C. SLN/anti-N9

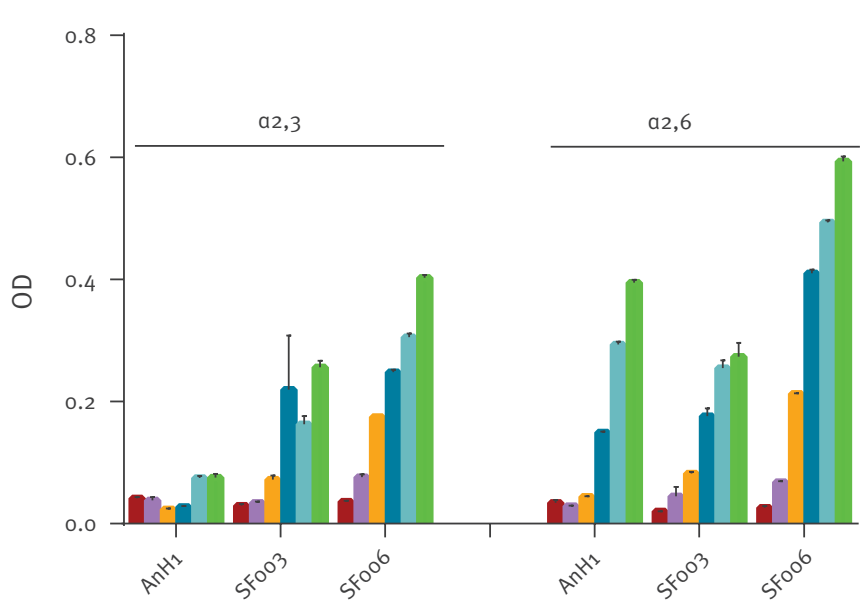

B. Di-SLN/anti-H7

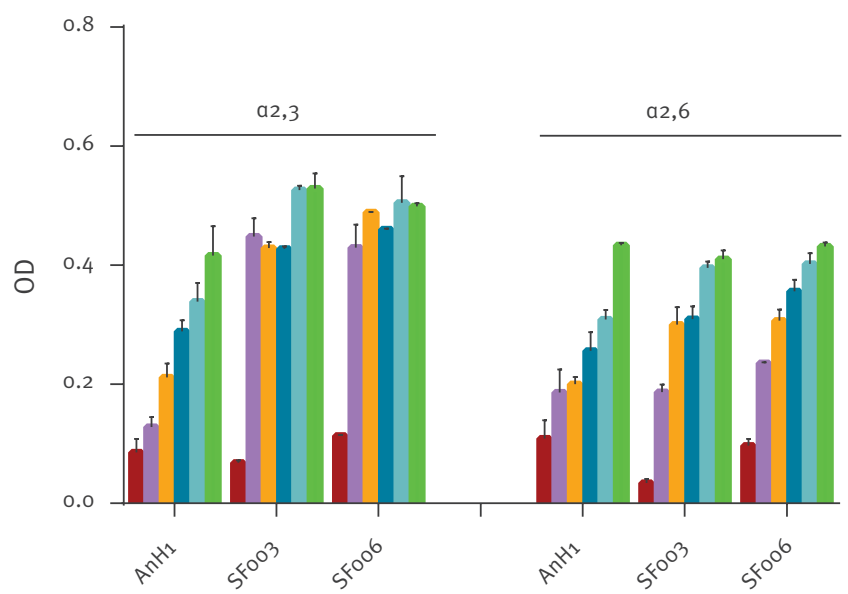

D. Di-SLN/anti-N9
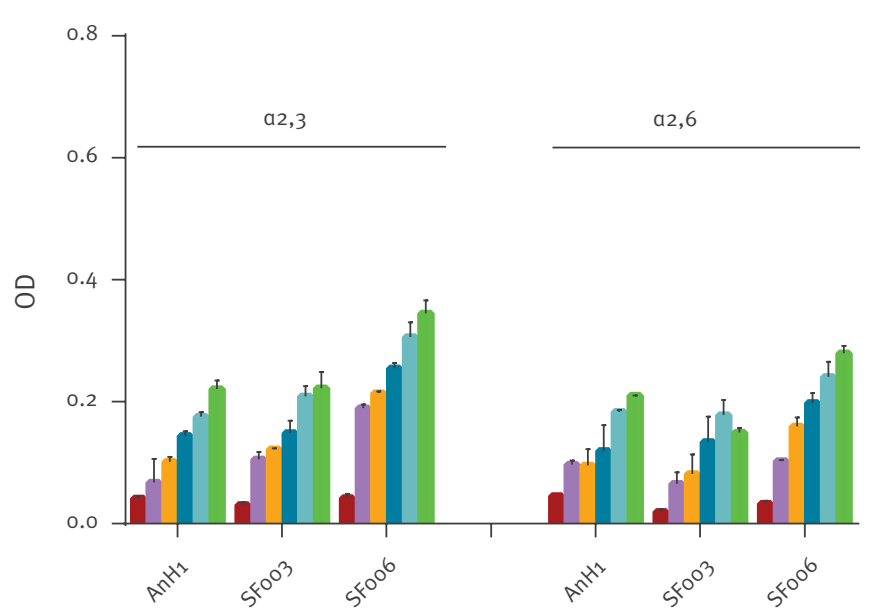

$0 \mu \mathrm{g} / \mathrm{mL}$ glycans
$0.625 \mu \mathrm{g} / \mathrm{mL}$ glycans

$1.25 \mu \mathrm{g} / \mathrm{mL}$ glycans

$5 \mu \mathrm{g} / \mathrm{mL}$ glycans

$2.5 \mu \mathrm{g} / \mathrm{mL}$ glycans

$10 \mu \mathrm{g} / \mathrm{mL}$ glycans

AnH1: A/Anhui/1/2013 (LPAI H7N9); LN: lactosamine (Galß1-4GlcNAc); OD: optical density; SFoo3: A/Guangdong/17SFoo3/2016 (HPAI H7N9); SFo06: A/Guangdong/17SFoo6/2017 (HPAI H7N9); 3'SLN: Neu5Aca2-3 linked to LN; 6'SLN: Neu5Aca2-6 linked to LN.

Each sample was tested in duplicate. Absorbance was read at $450 \mathrm{~nm}$. Binding profiles of tested viruses are presented with glycans of o, $0.625,1.25,2.5,5$ and $10 \mu \mathrm{g} / \mathrm{mL}$.

$(\mathrm{AnH} 1)$ were sensitive to the three NAls, while the $\mathrm{A} /$ Texas/12/2007 virus which contained the E119V substitution in the NA protein showed highly reduced inhibition to oseltamivir (mean: 798-fold increase in IC50) but normal inhibition to zanamivir and peramivir (Table 2). The HPAI H7N9 virus $\mathrm{SFoo}_{7}$ with $\mathrm{NA}-292 \mathrm{R}$ was similar to $\mathrm{AnH}_{1}$ and sensitive to all the three NAls. However, the substitution $\mathrm{R} 292 \mathrm{~K}$ in the NA protein induced a mean 53,855 -fold increase in the $\mathrm{IC}_{50}$ of oseltamivir, and a 3,556-fold and 73-fold increase in peramivir and zanamivir, respectively.

\section{Discussion}

Compared with other avian influenza viruses, LPAI $\mathrm{H}_{7} \mathrm{~N}_{9}$ and $\mathrm{HPAl} \mathrm{H}_{5} \mathrm{~N}_{1}$ are of most concern because of their high mortality and morbidity. LPAI H7N9 poses a higher risk for humans than HPAI $\mathrm{H}_{5} \mathrm{~N}_{1}$ because LPAI $\mathrm{H}_{7} \mathrm{~N} 9$ could bind sialic acid a2,6 human-type receptors while HPAI $\mathrm{H}_{5} \mathrm{~N}_{1}$ could not. Our data show that the HPAI $\mathrm{H}_{7} \mathrm{~N} 9$ viruses retained dual receptor binding properties, with slightly increased binding preference for both receptors compared with $\mathrm{LPAI} \mathrm{H}_{7} \mathrm{~N}_{9}\left(\mathrm{AnH}_{1}\right)$ viruses. It is well known that human upper respiratory tissues and 
TABLE 1

Haemagglutination inhibition reactions of human influenza A(H7N9) virus isolates, China, 2016-2017 (n = 16)

\begin{tabular}{|c|c|c|c|c|}
\hline \multirow{2}{*}{ Strains } & \multirow{2}{*}{ HA } & \multicolumn{3}{|c|}{ Titre of ferret antiserum to antigen } \\
\hline & & $\mathrm{AnH}_{1}$ & AnH1-RG & $\mathrm{SH}_{2}$ \\
\hline A/Anhui/1/2013 & 256 & 160 & 80 & 320 \\
\hline A/Anhui/1/2013-RG & 256 & 320 & 160 & 640 \\
\hline A/Shanghai/2/2013 & 128 & 320 & 160 & 640 \\
\hline A/Shanghai/2/2013-RG & 64 & 320 & 160 & 640 \\
\hline A/Fujian/02152/2017 & 1,024 & 160 & 40 & 160 \\
\hline A/Anhui/60936/2016 & 1,024 & 80 & 40 & 80 \\
\hline A/Jiangsu/06463/2017 & 1,024 & 320 & 80 & 160 \\
\hline A/Jiangsu/06454/2017 & 128 & 80 & 40 & 160 \\
\hline A/Jiangsu/60466/2016 & 32 & 160 & 40 & 80 \\
\hline A/Fujian/54840/2016 & 2,048 & 160 & 40 & 160 \\
\hline A/Jiangsu/6046o/2016 & 2,048 & 80 & 40 & 80 \\
\hline A/Hunan/02287/2017 & 512 & 160 & 40 & 80 \\
\hline A/Guangdong/6006o/2016 & 512 & 320 & 160 & 640 \\
\hline A/Guangdong/17SFoo4/2017 & 2,048 & 320 & 160 & 640 \\
\hline A/Guangdong/60923/2016 & 32 & 320 & 80 & 320 \\
\hline A/Guangdong/60061/2016 & 2,048 & 160 & 80 & 320 \\
\hline A/Hunan/06948/2017 & 2,048 & 40 & $<40$ & 80 \\
\hline A/Anhui/60933/2016 & 32 & $<40$ & $<40$ & $<40$ \\
\hline A/Guangdong/17SFoo3/2016 & 256 & $<40$ & $<40$ & $<40$ \\
\hline A/Guangdong/17SFoo6/2017 & 512 & 40 & $<40$ & 40 \\
\hline
\end{tabular}

AnH1: A/Anhui/1/2013; HA: haemagglutinin; RG: reverse genetic; SH2: A/Shanghai/2/2013.

Homologous titres are indicated in bold.

\section{TABLE 2}

Susceptibility of human isolates of highly pathogenic avian influenza A(H7N9) viruses to neuraminidase inhibitors, China, 2016 (n =2)

\begin{tabular}{|c|c|c|c|c|c|c|}
\hline \multirow[b]{2}{*}{ Viruses } & \multicolumn{2}{|c|}{ Oseltamivir } & \multicolumn{2}{|c|}{ Zanamivir } & \multicolumn{2}{|c|}{ Peramivir } \\
\hline & Mean $I C_{50}(n M) \pm S D$ & Fold change $^{a}$ & $\begin{array}{l}\text { Mean IC } \\
(n M) \pm S D^{\circ}\end{array}$ & Fold change $^{b}$ & $\begin{array}{l}\text { Mean IC } \\
(\mathrm{nM}) \pm S \mathrm{SD}^{\circ}\end{array}$ & 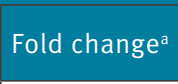 \\
\hline A/Anhui/1/2014 (H7N9) & $0.58 \pm 1.03$ & 1.0 & $0.66 \pm 1.07$ & 1.0 & $0.05 \pm 1.02$ & 1.0 \\
\hline $\begin{array}{l}\text { A/Guangdong/17SFoo3/2016 } \\
\left(\mathrm{H}_{7} \mathrm{~N}_{9}-292 \mathrm{R}\right)^{\mathrm{b}}\end{array}$ & $0.84 \pm 1.06$ & 1.4 & $0.95 \pm 1.12$ & 1.4 & $0.07 \pm 1.04$ & 1.4 \\
\hline $\begin{array}{l}\text { A/Guangdong/17SFo03/2016 } \\
(\mathrm{H} 7 \mathrm{~N} 9-292 \mathrm{~K})^{\mathrm{b}}\end{array}$ & $31236.00 \pm 1.68$ & $53,855.2$ & $69.33 \pm 1.10$ & 73.0 & $248.90 \pm 1.18$ & $3,555 \cdot 7$ \\
\hline $\begin{array}{l}\text { A/Beijing-Haidian/1942/2014 } \\
\left(\mathrm{H}_{3} \mathrm{~N}_{2}\right)\end{array}$ & $0.12 \pm 1.14$ & 1.0 & $0.12 \pm 1.09$ & 1.0 & $0.06 \pm 1.04$ & 1.0 \\
\hline $\mathrm{A} / \mathrm{Texas} / 12 / 2007\left(\mathrm{H}_{3} \mathrm{~N}_{2}-\mathrm{E} 119 \mathrm{~V}\right)^{\mathrm{b}}$ & $95.70 \pm 1.07$ & 797.5 & $0.93 \pm 1.10$ & 7.75 & $0.10 \pm 1.06$ & 1.7 \\
\hline
\end{tabular}

HPAI: highly pathogenic avian influenza; $\mathrm{IC}_{50}: 50 \%$ inhibitory concentration; SD: standard deviation.

a Compared with that of wild-type viruses. A/Texas/12/2007 ( $\left.\mathrm{H}_{3} \mathrm{~N}_{2}-\mathrm{E}_{119 V}\right)$ and $\mathrm{A} / \mathrm{Anhui} / 1 / 2014\left(\mathrm{H}_{7} \mathrm{~N} 9\right)$ were the wild-type influenza $\mathrm{A}\left(\mathrm{H}_{3} \mathrm{~N} 2\right)$ and influenza $\mathrm{A}\left(\mathrm{H}_{7} \mathrm{~N} 9\right)$ viruses, respectively.

${ }^{\mathrm{b}} \mathrm{N} 2$ numbering.

trachea contain mainly a2,6 receptors while lung tissue possesses mixtures of avian type a2,3 and human type a2, 6 receptors $[7,12]$. The persisting preference for both avian- and human-type receptors of $\mathrm{HPAl}_{7} \mathrm{~N}_{9}$ viruses may result in their circulation in poultry and possible transmission among humans.
Vaccination is the primary measure to control the spread of influenza virus infection in humans. Previously, WHO recommended A/Anhui/1/2013 (LPAI $\left.\mathrm{H}_{7} \mathrm{~N} 9\right)$ as the vaccine strain for influenza $A\left(\mathrm{H}_{7} \mathrm{~N} 9\right)$ virus. However, our data show that the newly emerged $\mathrm{HPAl} \mathrm{H}_{7} \mathrm{~N} 9$ viruses did not react strongly with the ferret antisera of LPAI H7N9 viruses. Therefore, WHO has 
recently recommended SFoo3 as an additional candidate vaccine virus.

Among the four commercially available NAIs, oseltamivir and zanamivir are the predominant NAls for influenza prophylaxis and treatment [13]. Our results show that $\mathrm{HPAl} \mathrm{H}_{7} \mathrm{~N}$ 9 viruses with the $292 \mathrm{~K}$ amino acid in the NA protein exhibited multi-drug resistance. The viral neuraminidase could acquire the R292K substitution as early as 2 days after administration of the antiviral drug. Further assessment of the fitness of drug-resistant viruses is urgently needed.

In summary, although the highly pathogenic influenza $\mathrm{A}\left(\mathrm{H}_{7} \mathrm{~N} 9\right)$ virus was thought to cause higher risk in poultry than the low-pathogenic virus, our study, especially regarding the receptor profile of $\mathrm{HPAl} \mathrm{H}_{7} \mathrm{~N} 9$ viruses, has implications on surveillance and control strategies not only in the animal sector but also for public health. Our study also highlighted the critical role of antiviral surveillance monitoring in the clinical management of influenza virus infection as an essential component of pandemic preparedness.

\section{Acknowledgements}

This study was supported by the National Mega-projects for Infectious Diseases (2014ZX10004002 to YS) and the National Key Research and Development Program of China (2016YFC1200200 to YS and 2016YFD0500208 to DW). The contents of this article are solely the responsibility of the authors and do not necessarily represent the views of China CDC or other organisations.

\section{Conflict of interest}

None declared.

\section{Authors' contributions}

YS and DW designed the study. JZ, ZL, XL, WH, SZ, WC, HW, JT, LL and JD performed the study. WZ analysed the data and drafted the manuscript. WFZ, JFZ, LY and YS revised the manuscript.

\section{Reference}

1. Gao R, Cao B, Hu Y, Feng Z, Wang D, Hu W, et al. Human infection with a novel avian-origin influenza $A\left(\mathrm{H}_{7} \mathrm{~N} 9\right)$ virus. $\mathrm{N}$ Engl J Med. 2013;368(20):1888-97.PMID: 23577628

2. World Health Organization (WHO). Human infection with avian influenza $\mathrm{A}\left(\mathrm{H}_{7} \mathrm{~N} 9\right)$ virus - China. Disease outbreak news. Geneva: WHO; 2017. Available from:http://www.who.int/csr/ don/27-february-2017-ah7n9-china/en/

3. World Organisation for Animal Health (OIE). Manual of diagnostic tests and vaccines for terrestrial animals. Chapter 2.3.4. Avian influenza (infection with avian influenza viruses). Paris: OIE; [Accessed: 2 May 2017]. Available from: http:// www.oie.int/fileadmin/Home/eng/Health_standards/ tahm/2.03.04_Al.pdf

4. Zhou J, Wang D, Gao R, Zhao B, Song J, Qi X, et al. Biological features of novel avian influenza $A\left(\mathrm{H}_{7} \mathrm{Ng}\right)$ virus. Nature. 2013;499(7459):500-3. DOI: 10.1038/nature12379 PMID: 23823727

5. Shi Y, Zhang W, Wang F, Qi J, Wu Y, Song H, et al. Structures and receptor binding of hemagglutinins from human-infecting
$\mathrm{H}_{7} \mathrm{~N} 9$ influenza viruses. Science. 2013;342(6155):243-7. DOI: 10.1126/science.1242917 PMID: 24009358

6. Childs RA, Palma AS, Wharton S, Matrosovich T, Liu Y, Chai $W$, et al. Receptor-binding specificity of pandemic influenza $A\left(\mathrm{H}_{1} \mathrm{~N}_{1}\right) 2009$ virus determined by carbohydrate microarray. Nat Biotechnol. 2009;27(9):797-9. DOI: 10.1038/nbto909-797 PMID: 19741625

7. Chandrasekaran A, Srinivasan A, Raman R, Viswanathan K, Raguram S, Tumpey TM, et al. Glycan topology determines human adaptation of avian $\mathrm{H}_{5} \mathrm{~N}_{1}$ virus hemagglutinin. Nat Biotechnol. 2008;26(1):107-13. DOI: 10.1038/nbt1375 PMID: 18176555

8. Benton DJ, Wharton SA, Martin SR, McCauley JW. Role of Neuraminidase in Influenza $\mathrm{A}(\mathrm{H} 7 \mathrm{~N} 9)$ Receptor Binding. J Virol. 2017;JVI.02293-16. DOI: 10.1128/JVI.02293-16 PMID: 28356530

9. World Health Organization (WHO) Collaborating Centers from Reference and Research on Influenza. Concepts and procedures for laboratory-based influenza surveillance / prepared by the WHO Collaborating Centers for Reference and Research on Influenza. 1982: Washington DC: United States Department of Health and Human Services. p. pB17-35.

10. Hurt AC, Holien JK, Barr IG. In vitro generation of neuraminidase inhibitor resistance in $\mathrm{A}\left(\mathrm{H}_{5} \mathrm{~N}_{1}\right)$ influenza viruses.Antimicrob Agents Chemother. 2009;53(10):4433-40. DOI: 10.1128/AAC.00334-09 PMID: 19651908

11. Okomo-Adhiambo M, Nguyen HT, Abd Elal A, Sleeman K, Fry AM, Gubareva LV. Drug susceptibility surveillance of influenza viruses circulating in the United States in 20112012: application of the WHO antiviral working group criteria. Influenza Other Respi Viruses. 2014;8(2):258-65. DOI: 10.1111/ irv.12215 PMID: 24299049

12. Walther T, Karamanska R, Chan RW, Chan MC, Jia N, Air G, et al. Glycomic analysis of human respiratory tract tissues and correlation with influenza virus infection. PLoS Pathog. 2013;9(3):e1003223. DOI: 10.1371/journal.ppat.1003223 PMID: 23516363

13. Webster RG, Govorkova EA. Continuing challenges in influenza. Ann N Y Acad Sci. 2014;1323(1):115-39. DOI: 10.1111/nyas.12462 PMID: 24891213

\section{License and copyright}

This is an open-access article distributed under the terms of the Creative Commons Attribution (CC BY 4.0) Licence. You may share and adapt the material, but must give appropriate credit to the source, provide a link to the licence, and indicate if changes were made.

This article is copyright of the authors, 2017. 